\title{
Purification and characterization of a novel thermostable luciferase from Benthosema pterotum
}

\author{
Ahmad Abolpour Homaei ${ }^{a}$, Asma Bahari Mymandi ${ }^{b}$, Reyhaneh Sariri ${ }^{c}$, Ehsan Kamrani ${ }^{\text {b }}$, \\ Roberto Stevanato ${ }^{\mathrm{d}}$, Seyed-Masoud Etezad ${ }^{\mathrm{a}}$, Khosro Khajeh ${ }^{\mathrm{a}, *}$ \\ a Department of Biochemistry, Faculty of Biological Sciences, Tarbiat Modares University, Tehran, Iran \\ ${ }^{\mathrm{b}}$ Department of Biology, Faculty of Sciences, University of Hormozgan, Bandar Abbas, Iran \\ ' Department of Biology, Faculty of Sciences, University of Guilan, Rasht, Iran \\ d Department of Molecular Sciences and Nanosystems, University Ca' Foscari of Venice, Italy
}

\section{A R T I C L E I N F O}

\section{Article history:}

Received 28 February 2013

Received in revised form 30 May 2013

Accepted 30 May 2013

Available online 11 June 2013

\section{Keywords:}

Benthosema pterotum luciferase

Enzyme purification

Bioluminescence

Persian Gulf

\begin{abstract}
A B S T R A C T
A novel luciferase from Benthosema pterotum, collected from Port of Jask, close to Persian Gulf, was purified for the first time, using Q-Sepharose anion exchange chromatography. The molecular mass of the novel enzyme, measured by SDS-PAGE technique, was about $27 \mathrm{kDa}$ and its $K_{m}$ value is $0.4 \mu \mathrm{M}$; both values are similar to those of other coelenterazine luciferases. B. pterotum (BP) luciferase showed maximum intensity of emitted light at $40{ }^{\circ} \mathrm{C}$, in $20 \mathrm{mM}$ Tris buffer, $\mathrm{pH} 9$ and $20 \mathrm{mM}$ magnesium concentration. Experimental measurements indicated that BP luciferase is a relatively thermostable enzyme; furthermore it shows a high residual activity at extreme $\mathrm{pH}$ values. Its biological activity is strongly inhibited by $1 \mathrm{mM} \mathrm{Cu}^{2+}, \mathrm{Zn}^{2+}$ and $\mathrm{Ni}^{2+}$, while calcium and mainly magnesium ions strongly increase BP luciferase activity. The B. pterotum luciferase generated blue light with a maximum emission wavelength at $475 \mathrm{~nm}$ and showed some similarity with other luciferases, while other parameters appeared quite different, in this way, confirming that a novel protein has been purified.
\end{abstract}

(C) 2013 Published by Elsevier B.V.

\section{Introduction}

Bioluminescence is referred to the light emission by a living organism due to a specific biochemical reaction. This interesting feature of the organisms could highly influences behavioral and ecosystem dynamics [1]. Luminescence, mostly observed in marine species, is generally higher in deep-living genera than in benthic or shallow organisms. However, among creatures living in land, fireflies, beetles, springtails and fungi have shown some bioluminescent activities [1,2]. Myctophids are mesopelagic fishes from family of Myctophidae, represented by about 250 species in 33 genera. They are called "Lanternfishes", a family of the largest fish species inhabit in deep sea and oceans but not in the Arctic [3-5]. Although a significant number of these species are identified, biochemical knowledge about their bioluminescence is limited and studies of the photochemical systems, of unidentified species are of scientific importance [6-8]. Benthosema pterotum species from this family are among the most abundant and wide spread fishes in deep oceans. Their average length is usually $15 \mathrm{~mm}$, ranging from 2 to $30 \mathrm{~mm}$, and their weight from 2 to $6 \mathrm{~g}$. They have a specific big and shiny head with oval eyes and small body; color varies

\footnotetext{
* Corresponding author. Tel./fax: +98 2182884717

E-mail address: khajeh@modares.ac.ir (K. Khajeh).
}

from greenish silver in shore species to dark brown for deep sea species [3,5]. The most specific feature that discriminates them from all similar organisms in the sea is the presence of luminescence photophores on their head and body. B. pterotum shows the presence of non-bacterial bioluminescent organs known as "Photophores", which are ventrally arranged and species-specific (Fig. 1). These are complex structures consisting of modified cuplike (lens) scales, containing photogenic tissue [9-11]. Expanded chemical knowledge on their luminescence is rather meager at present. Clearly, some further study is needed to identify the luminescence system of this species. Discussing the type of luminescence systems involved, they might utilize a luciferin-luciferase system, a photoprotein system, or other type of luminescence system that is not yet known. In this research, the photosystems of $B$. pterotum has been studied for the first time and a novel luciferase, the enzyme catalyzing the reaction responsible of the emission of blue light, was purified and characterized. Considering the fact that B. pterotum is exclusively found in Persian Gulf and the luciferase responsible for its unique bioluminescence behavior it not studied so far, we aimed to extract, purify, identify and characterize this novel luciferase. The specific information obtained from this research has now opened the way to further characterize the enzyme and design for its various ecological, industrial and medical applications. 


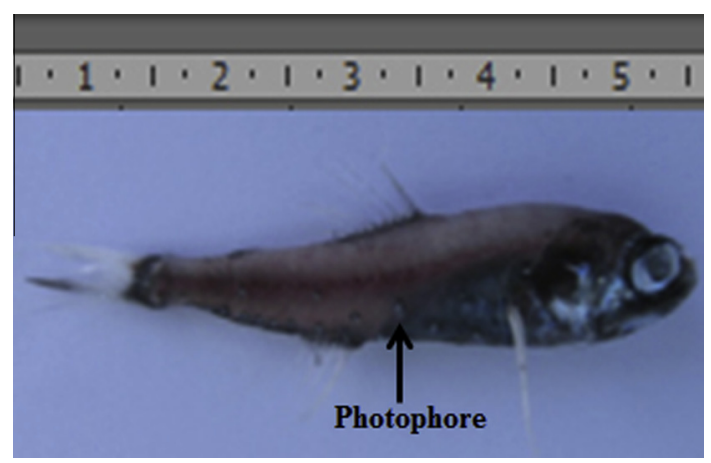

Fig. 1. Benthosema pterotum from Jask port, Persian Gulf; position of luminescence photophores is indicated.

\section{Materials and methods}

\subsection{Materials}

Coelenterazine hcp was purchased from Sigma (St. Louis, MO, USA) and Q-Sepharose from Pharmacia (Uppsala, Sweden). All other chemicals were reagent grade and purchased from Merck (Darmstadt, Germany).

\subsection{Specimen collection}

B. pterotum (Lantern fish), caught from Port of Jask, was immediately frozen in liquid nitrogen and transported to our enzymology laboratory in Tehran. The frozen samples were then stored at $-80^{\circ} \mathrm{C}$ until used.

\subsection{Selective extraction and purification of luciferase from B. pterotum photogenic organ}

The yellowish photogenic organ was washed with distilled water and scraped with scalpel from luminescent photophores. Photogenic tissue was re-suspended in $10 \mathrm{ml}$ of lysis buffer (20 mM Tris- $\mathrm{HCl}, \mathrm{pH} 7.8,0.5 \mathrm{mM} \mathrm{NaCl}, 50 \mathrm{mM}$ EDTA and $1 \mathrm{mM}$ PMSF). The suspension was subjected to sonic disruption at $0{ }^{\circ} \mathrm{C}$ (10 s on, $45 \mathrm{~s}$ off for $15 \mathrm{~min}$ ) and the cell debris were discarded by centrifugation at $15,000 \mathrm{~g}$ for $20 \mathrm{~min}$. The supernatant (cell free extract) was subjected to ammonium sulfate precipitation (85\% saturation). The protein was then dissolved in minimal amount of $20 \mathrm{mM}$ Tris- $\mathrm{HCl}$ buffer, $\mathrm{pH} 7.8$ and dialyzed against the same buffer for $24 \mathrm{~h}$ at $4{ }^{\circ} \mathrm{C}$, changing dialysis buffer every $8 \mathrm{~h}$. The dialyzed sample was loaded onto Q-Sepharose column equilibrated with Tris buffer. After washing the column, adsorbed proteins were eluted with a linear 0-2 $\mathrm{M} \mathrm{NaCl}$ gradient in $20 \mathrm{mM}$ Tris- $\mathrm{HCl}$ buffer ( $\mathrm{pH} 7.8$ ). The flow rate was $3 \mathrm{ml} / \mathrm{min}$ and $2 \mathrm{ml}$ fractions were collected. Fractions exhibiting luciferase activity were pooled and concentrated by an Amicon 8050 ultrafiltration system equipped with a $10 \mathrm{kDa}$ cut-off membrane.

The proteins were identified by sodium dodecyl sulfate polyacrylamide gel electrophoresis (SDS-PAGE) using a Mini-PROTEAN electrophoretic system (BioRad). Electrophoresis was carried out at a constant current of $80 \mathrm{~mA} \mathrm{[12]} \mathrm{and} \mathrm{the} \mathrm{gels} \mathrm{were} \mathrm{stained} \mathrm{with}$ Coomassie brilliant blue R-250 [13].

\subsection{Spectral measurements, determination of bioluminescence activity} and protein concentration

Bioluminescence emission spectra were obtained using a Biotek Synergy H4 Multi-Mode Plate Reader with its excitation lamp turned off; operating at room temperature in the range 400$700 \mathrm{~nm}$ in a plate reader.The spectra were automatically corrected for the spectral photosensitivity of the equipment with an internal program identified as $\mathrm{M}$-correct on the instrument by the manufacture. The bioluminescence spectra were measured in $20 \mathrm{mM}$ Tris- $\mathrm{HCl}, \mathrm{pH} 7.8$, and initiated by injection of $\mathrm{MgCl}_{2}$ solution in the same buffer. The concentration of free magnesium was around $30 \mathrm{mM}$ in order to provide an approximately constant light level during the spectral scan. In cases where a substantial change in bioluminescence intensity took place during the spectral scan, the data points were also corrected for bioluminescence decay. The emission slit was $17 \mathrm{~nm}$, emission step was $10 \mathrm{~nm}$, delay after play movement was $100 \mathrm{~ms}$, and the scan rate equal to $170 \mathrm{~nm} / \mathrm{s}$.

Luciferase activity was measured by a Sirius tube luminometer, Berthold Detection System, Germany. In a typical experiment, $25 \mu$ of the enzyme solution was mixed with coelenterazine hcp (luciferin) as substrate, in $20 \mathrm{mM}$ Tris- $\mathrm{HCl}$ buffer, $\mathrm{pH} 7.8$, and the light emitted immediately recorded and integrated at $0.2 \mathrm{~s}$ intervals. $K_{m}$ and $V_{\max }$ values were determined by Lineweaver-Burk plots. All experiments were carried out in triplicate at least. Protein concentration was estimated by the Bradford method, using bovine serum albumin as standard [14].

\subsection{Effect of $\mathrm{pH}$ and temperature on enzyme activity and stability}

Luciferase activity versus $\mathrm{pH}$ was measured at room temperature in the range $2-12 \mathrm{pH}$ values, using a mixed buffer containing $20 \mathrm{mM}$ acetate, phosphate and glycine, according to the assay conditions.

In order to verify the activity dependence with temperature, enzyme activity were carried out in the range of $10-65^{\circ} \mathrm{C}$, in $20 \mathrm{mM}$ Tris- $\mathrm{HCl}$ buffer $\mathrm{pH} 7.8$, as described above.

For determination of optimal reaction $\mathrm{pH}$ and temperature, the maximum activities obtained under the conditions tested were taken as $100 \%$.

Enzyme stability to $\mathrm{pH}$ was checked incubating the enzyme at room temperature in $20 \mathrm{mM}$ of mixed buffer at $\mathrm{pH} 3$ and 12 for different intervals of time; then $\mathrm{pH}$ value was adjusted to 7.4 and the residual activity measured.

Luciferase thermal stability was measured incubating the enzyme in $20 \mathrm{mM}$ Tris- $\mathrm{HCl}$ buffer $\mathrm{pH} 7.4$, at 55,65 and $90^{\circ} \mathrm{C}$ for different intervals of time; the solution was then cooled on ice and the residual activity determined under the assay conditions.

Control measurements were carried out determining the activity of the same enzyme solutions kept on ice for the thermal stability and in the buffer at $\mathrm{pH} 7.8$ for the $\mathrm{pH}$ stability experiment.

\subsection{Effect of metal ions on BP luciferase activity}

Enzyme activity was measured at the usual experimental conditions in the presence of various chloride metal ions in the concentration range of $0-40 \mathrm{mM}$.

\subsection{Calculation of thermodynamic parameters}

The rate constants of luciferatic reaction $\left(k_{\text {cat }}\right)$ were used to calculate the activation energy according to the Arrhenius equation [15].

$k=A e^{-E a / R T}$

where $k\left(\mathrm{~s}^{-1}\right)$ is the rate constant at temperature $T(\mathrm{~K}), A$ is a preexponential factor related to steric effects and the molecular collision frequency, $R$ is the gas constant $\left(8.314 \mathrm{~J} \mathrm{~mol}^{-1} \mathrm{~K}^{-1}\right)$, and $E_{a}$ the activation energy of the reaction. Hence, a plot of $\ln k$ as a function of $1 / T$ gives a curve with slope of $-E a / R$. The thermodynamic parameters of activation were determined as follows:

$\Delta G^{\#}=R T \ln \left(K_{B} T / h\right)-R T \ln k_{\text {cat }}$ 


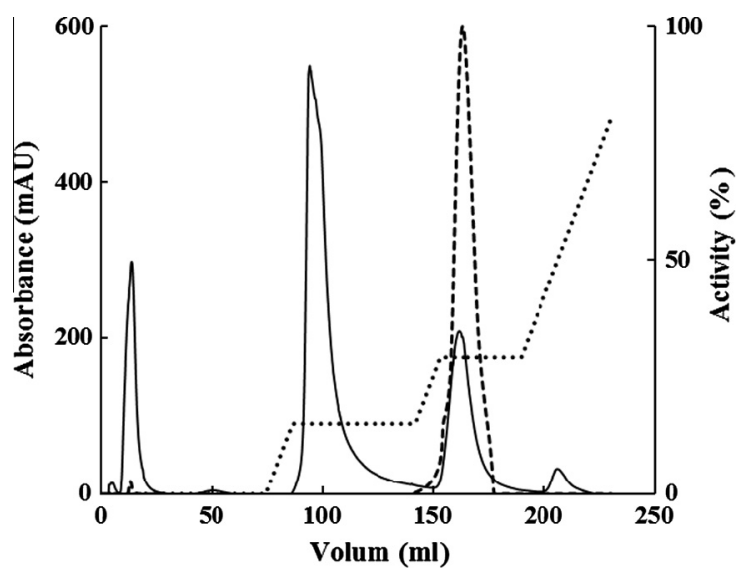

Fig. 2. Anion-exchange chromatography on a Q-Sepharose column. The extracts (in $20 \mathrm{mM}$ Tris- $\mathrm{HCl}$ buffer, $\mathrm{pH}$ 7.8) were applied to the column which was equilibrated with the same buffer. The BP luciferase was eluted with a linear $0-2 \mathrm{M} \mathrm{NaCl}$ gradient at a flow rate of $3 \mathrm{ml} / \mathrm{min}$. Chromatographic profile of luciferase activity (dotted line), protein absorbance (solid line) in Q-Sepharose eluate and salt concentrations (dash dot line).

Table 1

Purification procedures of BP Luciferase from Benthosema pterotum.

\begin{tabular}{llllll}
\hline $\begin{array}{l}\text { Steps of } \\
\text { purification }\end{array}$ & $\begin{array}{l}\text { Total } \\
\text { protein } \\
(\mathrm{mg})\end{array}$ & $\begin{array}{l}\text { Total } \\
\text { activity } \\
\left(\times 10^{5} \mathrm{RLU}\right)\end{array}$ & $\begin{array}{l}\text { Specific activity } \\
\left(\times 10^{5} \mathrm{RLU} \mathrm{mg}^{-1}\right)\end{array}$ & $\begin{array}{l}\text { Yield } \\
(\%)\end{array}$ & $\begin{array}{l}\text { Purification } \\
\text { fold }\end{array}$ \\
\hline $\begin{array}{l}\text { Cell extract } \\
\left(\mathrm{NH}_{4}\right)_{2} \mathrm{SO}_{4} \\
\text { precipitation }\end{array}$ & 33 & $161 \pm 12$ & $1.3 \pm 0.1$ & 100 & 1 \\
\begin{tabular}{c} 
Q-Sepharose \\
\hline
\end{tabular} & 12 & $118 \pm 7$ & $4.1 \pm 0.1$ & 83.8 & 3.2 \\
\hline
\end{tabular}

$\Delta H^{\#}=E_{a}-R T$

$\Delta S^{\#}=\left(\Delta H^{\#}-\Delta G^{\#}\right) / T$

where $k_{B}$ is the Boltzman constant $\left(1.3805 \times 10^{-23} \mathrm{~J} \mathrm{~K}^{-1}\right), h$ the Planck's constant $\left(6.6256 \times 10^{-34} \mathrm{~J} \mathrm{~s}\right)$, and $k_{\text {cat }}\left(\mathrm{s}^{-1}\right)$ is the rate constant at temperature $T(\mathrm{~K})$.

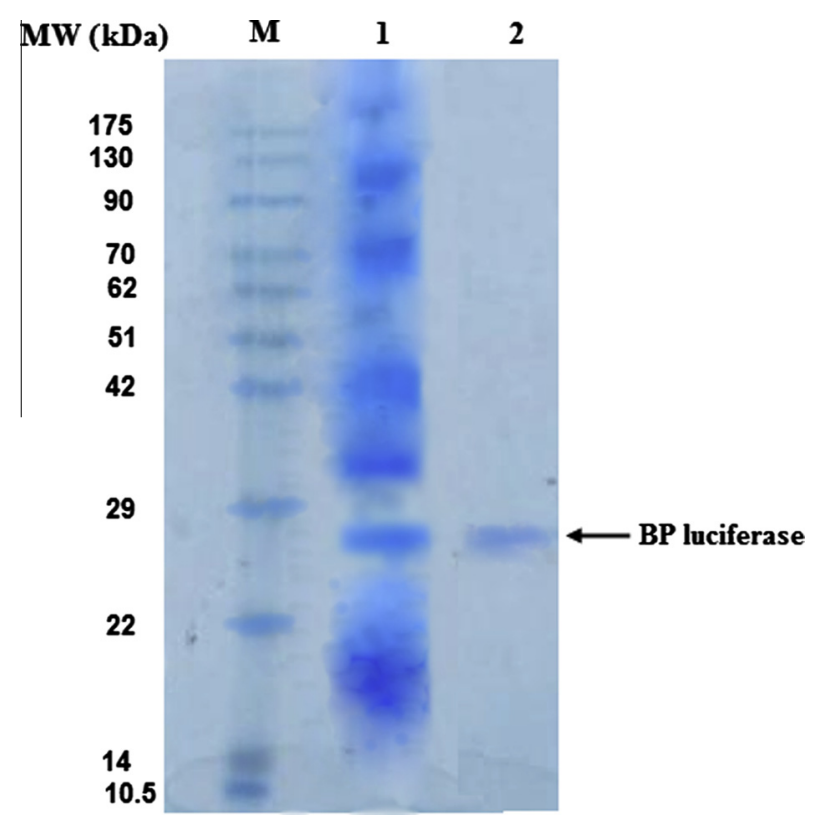

Fig. 3. SDS-PAGE of BP luciferase after purification by chromatography. Lane 1: cell extract; lane 2: purified luciferase. First lane is the molecular mass marker.
All of the results are taken as the mean value obtained from at least three repeated experiments in a typical run to confirm reproducibility.

\section{Results and discussion}

3.1. Extraction, purification and molecular mass determination of the enzyme

The BP luciferase was purified from B. pterotum using Q-Sepharose chromatography. The supernatant obtained from cell free extract was concentrated by precipitation with ammonium sulfate. The resulting protein solution was then loaded into a Q-Sepharose column. BP luciferase was eluted from the third peak with $0.29 \mathrm{M}$ $\mathrm{NaCl}$ (Fig. 2). The overall purification procedure is summarized in Table 1.

Fractions exhibiting luciferase activity were pooled out and concentrated using Amicon 8050 ultrafiltration system equipped with a $10 \mathrm{kDa}$ membrane cut-off. SDS-PAGE course showed electrophoretic purity grade for the enzyme. The molecular mass of BP luciferase was about $27 \mathrm{kDa}$ (Fig. 3), a value in the range of that of other coelenterazine luciferases, with the exception of Oplopborus luciferase (gracilirostris) which shows a protein molecular mass value about four times higher [16-20].

The specific activity of BP luciferase was $1.3 \times 10^{5} \mathrm{RLU} \mathrm{mg}^{-1}$ and $4.1 \times 10^{5} \mathrm{RLU} \mathrm{mg}^{-1}$ after cell extraction and ammonium sulfate precipitation, respectively. In the Q-Sepharose anion exchange chromatography, the BP luciferase was separated from most of extra cellular proteins. It was shown that luciferatic specific activity was $10 \times 10^{5} \mathrm{RLU} \mathrm{mg}^{-1}$.

\subsection{BP luciferase apparent kinetic constants and bioluminescence emission spectra}

BP luciferase activity was assayed at different coelenterazine concentrations in the range $0.1-3.3 \mu \mathrm{M}$ substrate. In Table 2 columns $1-4$, the values of $K_{m}, V_{\text {max }}, k_{\text {cat }}$ and $k_{\text {cat }} / K_{m}$, are reported. $K_{m}$ value of BP luciferase is in good agreement, varying of about \pm 3 times, with that of several other luciferases reported in literature [20-22], and it appears very low, indicating high affinity for the substrate. Like the most bioluminescence sea animals, BP luciferases generated blue light with a maximum emission wavelength at $475 \mathrm{~nm}$ (Fig. 4). Coelenterazine luciferases have been isolated from about 10 kinds of organisms, including the anthozoans Renilla and Ptilosarcus, the scyphozoan jellyfish Periphylla, three kinds of decapod shrimps, and two copepod species; some of them have been cloned. All of the luciferases cause the emission of a bluish light when they catalyze the oxidation of coelenterazine [20].

\subsection{Temperature and $\mathrm{pH}$ effect on enzyme activity and stability}

From Fig. 5a, where the behavior of BP luciferase activity with temperature in the range of $10-65^{\circ} \mathrm{C}$ is reported, it appears that temperature of maximum activity is $40^{\circ} \mathrm{C}$, a value similar of that found for Decapod shrimp, but higher than that referred to Ptilosarcus luciferase $\left(23^{\circ} \mathrm{C}\right)$ and Renilla luciferase $\left(32^{\circ} \mathrm{C}\right)$ [20]. Furthermore, residual activity is high, more than $50 \%$ of the maximum, in a wide temperature range (from about 20 to $55^{\circ} \mathrm{C}$ ) if compared with other coelenterazine luciferases. Moreover, it appears that about $30 \%$ of its maximum bioluminescence activity is retained at low $\left(10^{\circ} \mathrm{C}\right)$ and very high $\left(65^{\circ} \mathrm{C}\right)$ temperatures. In the bioluminescence systems of Cypridina, Latia, Chaetopterus, the relative activity decrease steeply when the temperature is raised, and become almost zero at a temperature higher than $40{ }^{\circ} \mathrm{C}$ [23]. 
Table 2

The apparent kinetic constants of BP luciferase. An enzyme concentration of $0.08 \mathrm{mg} / \mathrm{mL}$ for all kinetic measurements was used.

\begin{tabular}{|c|c|c|c|c|c|c|c|}
\hline \multicolumn{4}{|c|}{ Kinetics parameters } & \multicolumn{4}{|l|}{ Activation } \\
\hline$K_{m}(\mu \mathrm{M})$ & $V_{\max }(\mathrm{RLU})$ & $k_{\text {cat }}\left(\mathrm{s}^{-1}\right)$ & $k_{\mathrm{cat}} / K_{m}\left(\mathrm{~s}^{-1} \mu \mathrm{M}^{-1}\right)$ & $E_{a}(\mathrm{kcal} / \mathrm{mol})$ & $\Delta H^{\#}(\mathrm{kcal} / \mathrm{mol})$ & $\Delta G^{\#}(\mathrm{kcal} / \mathrm{mol})$ & $\Delta S^{\#}(\mathrm{cal} / \mathrm{mol} \mathrm{K})$ \\
\hline $0.4 \pm 0.01$ & $2 \pm 0.1 \times 10^{6}$ & $13.7 \pm 0.3$ & $34.3 \pm 0.8$ & $6.3 \pm 0.8$ & $5.7 \pm 0.3$ & $16.7 \pm 0.5$ & $-35 \pm 0.7$ \\
\hline
\end{tabular}

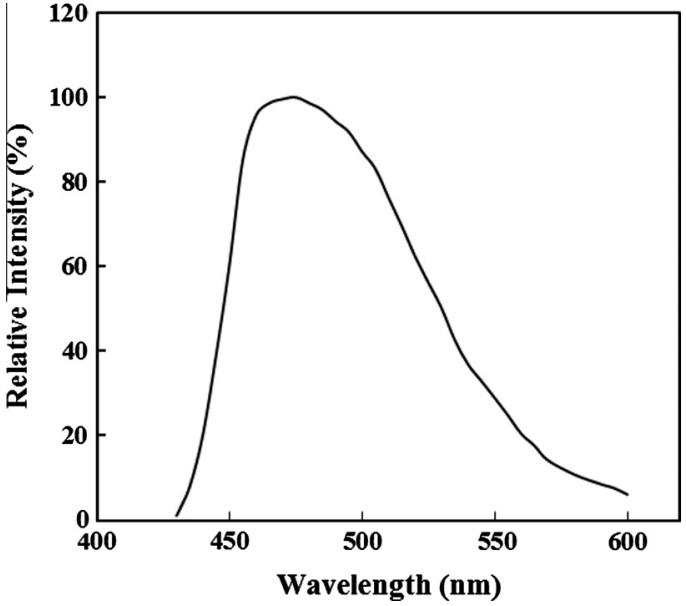

Fig. 4. Bioluminescence spectrum of coelentrazine catalyzed by BP luciferase in $20 \mathrm{mM}$ Tris- $\mathrm{HCl}, \mathrm{pH}$ 7.8. Light intensity is expressed in RLU; the wavelength is in nanometers; and the maximum emission was at $475 \mathrm{~nm}$. The initial concentration of magnesium was $30 \mathrm{mM}$.

From the Arrhenius plots (inset of Fig. 5a), graphed utilizing BP luciferase activity values in the temperature range of $10-40{ }^{\circ} \mathrm{C}$, a value of activation energy of the catalytic reaction of $6.3 \mathrm{kcal} \mathrm{mol}^{-1} \mathrm{~K}^{-1}$ was obtained. In Table 2, columns 6-8, values of activation free energy $\left(\Delta G^{\#}\right)$, activation enthalpy $\left(\Delta H^{\#}\right)$ and activation entropy $\left(\Delta S^{\#}\right)$ for the catalytic reaction are reported. The negative value of activation entropy $\left(\Delta S^{\#}\right)$ indicates that the structure of enzyme-substrate at transition state is characterized by very few degrees of freedom [24].

The time dependence of the BP luciferase stability with temperature, measured after incubating the enzyme at 55,65 and $90^{\circ} \mathrm{C}$, evidences a half life of more than $60 \mathrm{~min}$ at $\mathrm{T} \leqslant 65^{\circ} \mathrm{C}$ and of about

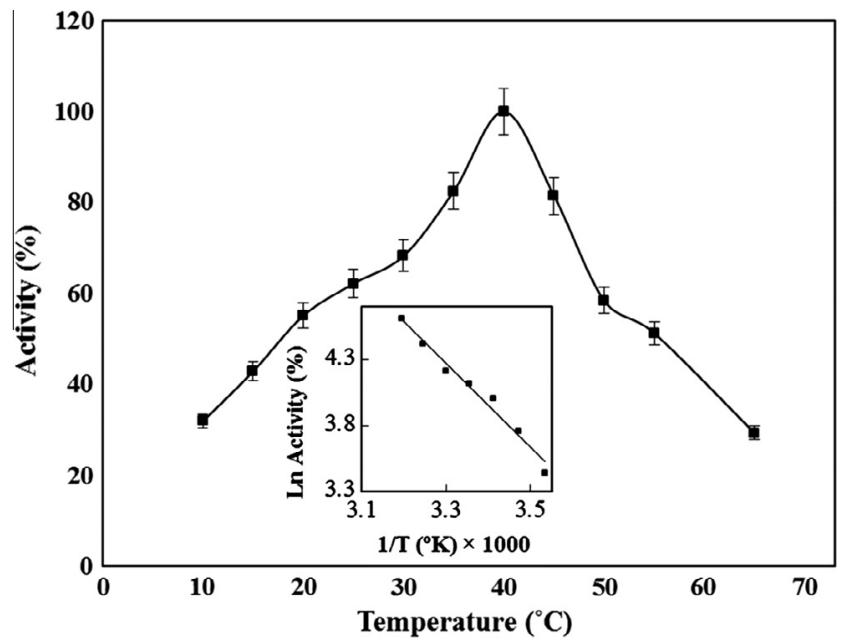

Fig. 5a. Behavior of BP luciferase activity with temperature in the range $10-65{ }^{\circ} \mathrm{C}$. The activity at optimal temperature was taken as $100 \%$. In the inset is the respective Arrhenius plots. Activation energies for BP luciferase was $6.3 \mathrm{kcal} \mathrm{mol}^{-1} \mathrm{~K}^{-1}$.

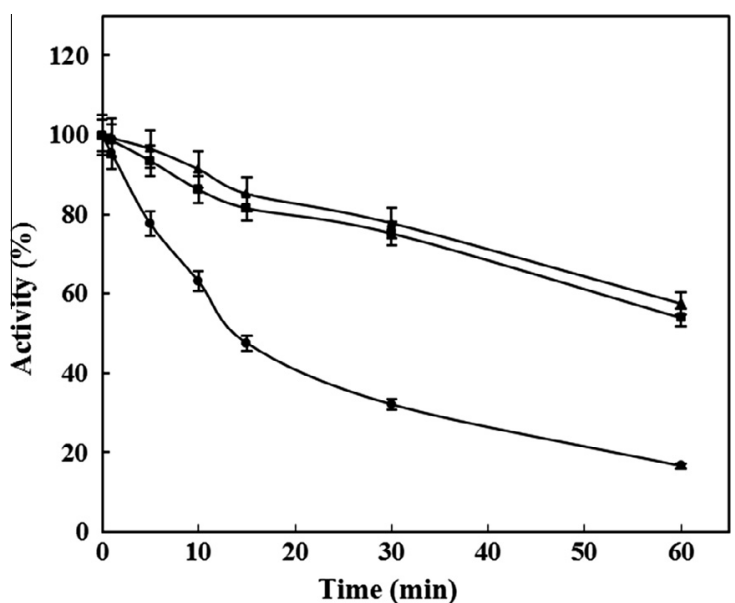

Fig. 5b. Irreversible inactivation of BP luciferase after incubation at different times at 55 (filled triangles), 65 (filled squares) and $90^{\circ} \mathrm{C}$ (filled circles). The activity of the same enzyme solution, kept on ice, was considered as the control (100\%).

15 min at $90{ }^{\circ} \mathrm{C}$ (Fig. 5b), values better than those referred to other luciferase, such as Gaussia luciferase, Cypridina noctiluca luciferase and Vargula hilgendorfii luciferase [25-27] which evidence negligible activity after $60 \mathrm{~min}$ incubation at $65^{\circ} \mathrm{C}$.

Activity vs $\mathrm{pH}$ behavior of BP luciferase in the $\mathrm{pH}$ range 2-12, shows wide asymmetrical bell-shaped dependence with a maximum value at about $\mathrm{pH} 9$ (Fig. 6a) and a relative high residual activity at $\mathrm{pH} 12$ ( $\cong 40 \%$ of the maximum). This profile appears similar to those of copepod Gaussia princeps luciferase, squid Watasenia scintillans and copepod Metridia luciferase [28-30]. In the case of some luciferase, photoproteins can be inactive at some $\mathrm{pH}$ values, without resulting in permanent inactivation. For example, the luminescence of euphausiids can be quenched at $\mathrm{pH} 6$, that of

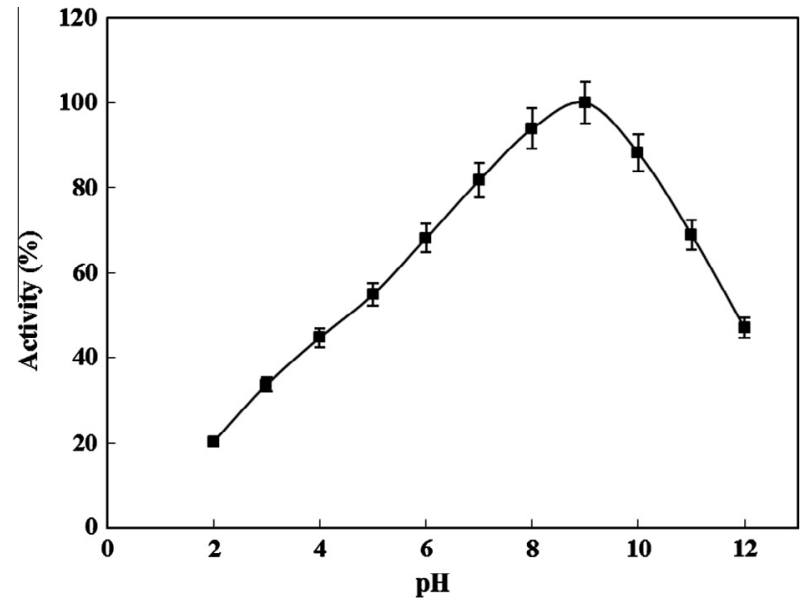

Fig. 6a. Behavior of BP Luciferase activity with $\mathrm{pH}$ in the range 2-12. The relative activity (\%) refers to the percentage of the initial reaction rate obtained by the enzyme in the maximum $\mathrm{pH}$ compere to other $\mathrm{pH}$ conditions. 


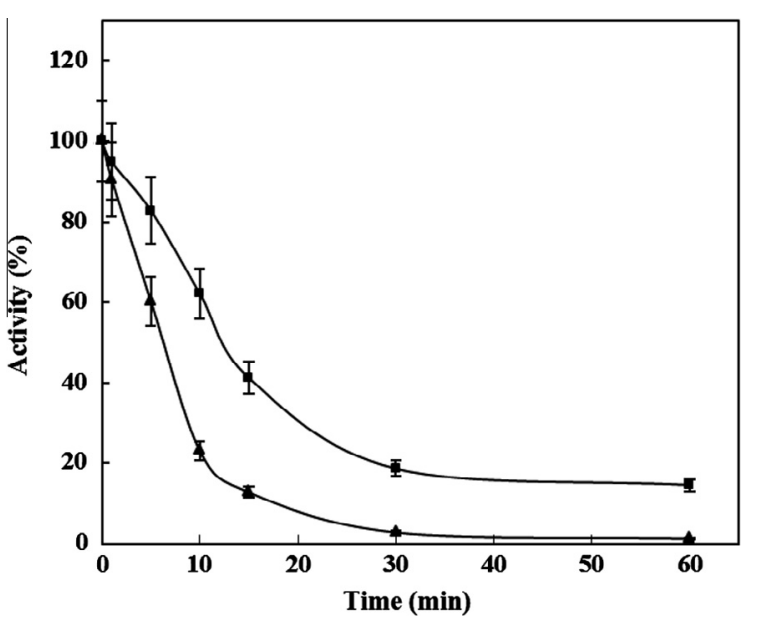

Fig. 6b. Irreversible inactivation of BP luciferase after incubation for different times at $\mathrm{pH} 3.0$ (filled triangles) and 12.0 (filled squares). The activity of untreated enzyme was taken as $100 \%$.

Table 3

Effect of various metal ions and their concentrations on BP luciferase. ${ }^{\text {. }}$

\begin{tabular}{|c|c|c|}
\hline Metal ions (mM) & & Relative activity (\%) \\
\hline Control (no add) & & 100 \\
\hline \multirow{4}{*}{$\mathrm{Na}^{+}$} & 1 & 100 \\
\hline & 5 & 96 \\
\hline & 10 & 93 \\
\hline & 20 & 87 \\
\hline \multirow[t]{4}{*}{$\mathrm{K}^{+}$} & 1 & 80 \\
\hline & 5 & 73 \\
\hline & 10 & 65 \\
\hline & 20 & 51 \\
\hline \multirow[t]{4}{*}{$\mathrm{NH}_{4}^{+}$} & 1 & 97 \\
\hline & 5 & 91 \\
\hline & 10 & 82 \\
\hline & 20 & 75 \\
\hline \multirow[t]{4}{*}{$\mathrm{Ca}^{2+}$} & 1 & 120 \\
\hline & 5 & 137 \\
\hline & 10 & 150 \\
\hline & 20 & 200 \\
\hline \multirow[t]{4}{*}{$\mathrm{Mg}^{2}$} & 1 & 350 \\
\hline & 5 & 1320 \\
\hline & 10 & 1960 \\
\hline & 20 & 3740 \\
\hline \multirow[t]{4}{*}{$\mathrm{Cu}^{2+}$} & 1 & 0.09 \\
\hline & 5 & 0.00 \\
\hline & 10 & 0.00 \\
\hline & 20 & 0.00 \\
\hline \multirow[t]{4}{*}{$\mathrm{Zn}^{2+}$} & 5 & 7 \\
\hline & 10 & 0.05 \\
\hline & 20 & 0.00 \\
\hline & 40 & 0.00 \\
\hline \multirow[t]{4}{*}{$\mathrm{Ni}^{2+}$} & 1 & 17.3 \\
\hline & 5 & 2.1 \\
\hline & 10 & 0.00 \\
\hline & 20 & 0.00 \\
\hline
\end{tabular}

a All metal ions were added as chloride salts.

aequorin at $\mathrm{pH} 4.2-4.4$, and the luciferase of the decapod shrimp Oplophorus becomes inactive at about $\mathrm{pH} 4$. In the case of Cypridina the acidification of an extract to $\mathrm{pH}$ below 5 induces irreversible inactivation of the luciferase [20].

The stability of the BP luciferase was measured at two extreme $\mathrm{pH}, 3.0$ and 12. As shown in Fig. 6b, the enzyme retains residual activity at alkaline $\mathrm{pH}$ values, indicatively about 15\%, after 60 min of incubation; while a nearly complete inactivation of enzyme at pH 3 after 30 min was observed.

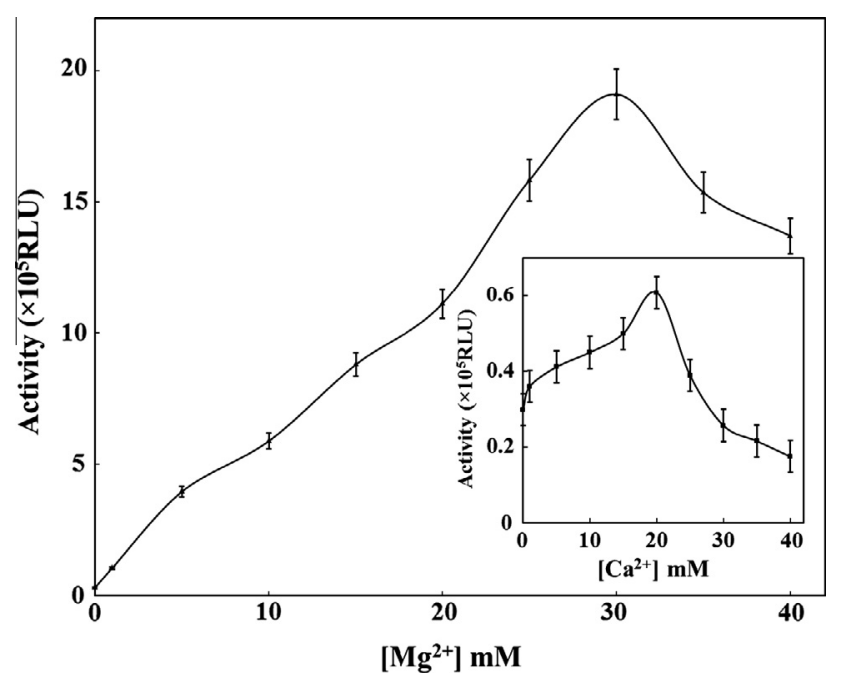

Fig. 7. Activity of BP luciferase at different concentrations of magnesium. The inset is the activity profile of the enzyme in various concentrations of calcium.

\subsection{Effect of metal ions on luminescence activity}

In Table 3, the results relative to the effect of metal ions at different concentration on luminescence activity are reported. Experimental data show that monovalent ions, such as $\mathrm{Na}^{+}, \mathrm{K}^{+}$, and $\mathrm{NH}_{4}^{+}$, have little effect decreasing activity with concentration, probably owing to ionic strength effect. On the contrary, strong inhibition was observed in the presence of the heavy metal ions $\mathrm{Cu}^{2+}, \mathrm{Zn}^{2+}$ and $\mathrm{Ni}^{2+}$. At $1 \mathrm{mM}$ ions concentration, residual luciferase activity was about $17 \%$ for nickel, $7 \%$ for zinc and $<1 \%$ for copper.

Among coelenterazine-type luciferase, Periphylla luciferases-O and luciferase-L were strongly inhibited by micromolar orders of $\mathrm{Cu}^{2+}[31]$ and BFP-aq was also strongly inhibited by $1 \mu \mathrm{M} \mathrm{Cu}^{2+}$ $[29,32,33]$. These results suggest that inhibition by $\mathrm{Cu}^{2+}$ of BP luciferase might occur in the same manner, but more extended research is needed in order to draw the exact mechanism.

Calcium and magnesium ions strongly increase BP luciferase activity, with a factor of about 2 in the case of $\mathrm{Ca}^{2+}$ and until 37 for $\mathrm{Mg}^{2+}$, according to literature [34-36]. In fact these ions participate as cofactor in bioluminescence reaction for many calcium and magnesium sensitive photosystems. The dependence of activity with concentration of these ions in a more large concentration range (Fig. 7) shows direct correlation until about $20 \mathrm{mM}$ in the case of calcium and $30 \mathrm{mM}$ in the case of magnesium, followed, in both the cases by a high activity decrease. Maximum activity of enzyme in the presence of $20 \mathrm{mM}$ calcium and $30 \mathrm{mM}$ magnesium was $0.6 \times 10^{5} \mathrm{RLU}$ and $20 \times 10^{5} \mathrm{RLU}$, respectively.

\section{Conclusion}

In the present study a new luciferase from the yellowish photogenic organ of $B$. pterotum was purified to homogeneity on SDSPAGE by column chromatography. The new luciferase shows some similarity with other luciferases, while other parameters appear very different, in this way confirming the originality of the investigation. Biotechnology applications appear very interesting, in particular on the possibility to generate some structural variations of BP luciferase in order to improve its bioluminescence applications.

\section{Acknowledgements}

Authors are grateful to the Tarbiat Modares University for the financial support to this research. 


\section{References}

[1] S.H.D. Haddock, M.A. Moline, J.F. Case, Bioluminescence in the Sea, Annu. Rev. Mar. Sci. 2 (2010) 443-493.

[2] E.A. Widder, Bioluminescence in the ocean: origins of biological, Chem., Ecol. Div., Sci. 328 (2010) 704-708.

[3] V. Catul, G. Manguesh, P.K. Karuppasamy, A review on mesopelagic fishes belonging to family Myctophidae, Rev. Fish Biol. Fish. 4 (2010) 123-128.

[4] P.K. Karuppasamy, S. George, N.G. Menon, Length-weight relationship of Benthosema pterotum (myctophid) in the deep scattering layer (DSL) of the eastern Arabian Sea, Ind. J. Fish. 4 (2008) 301-303.

[5] T. Valinassab, G.P. Pierce, K. Johansson, Lantern fish (Benthosema pterotum) resources as target for commercial exploitation in the Oman Sea, J. Appl. Ichthyol. 23 (2007) 573-577.

[6] A.T. Barnes, J.F. Case, The luminescence of lanternfish (Myctophidae): spontaneous activity and responses to mechanical, electrical and chemical stimulation, J. Exp. Mar. Biol. Ecol. 115 (1974) 203-221.

[7] H.G. Moser, W. Watson, Myctophiformes, in: W.J. Richards, (Ed.), Early stages of Atlantic fishes: an identification guide for the Western Central North Atlantic, first ed. Inc. Net, Library, 2006, pp. 461-580.

[8] J.F. Rees, B. De Wergifosse, O. Noiset, M. Dubuisson, B. Janssens, E.M Thompson, The origins of marine bioluminescence: turning oxygen defense mechanisms into deep sea communications tools, J. Exp. Biol. 201 (1998) 1211-1221.

[9] P.A. Hulley, Lanternfishes-Myctophidae, in: W. Fischer, J.C. Hureau, (Eds.), FAO species identification sheets for fishery purposes Southern Ocean, FAO, 1985, pp. 316-322.

[10] M.L.J. Stiassny, Myctophidae-Lanternfishes, in: The tree of lifeweb project, http://tolweb.org/Myctophidae/ 15174/1997.01.01, 1997, (accessed 12.02.12).

[11] E.H. White, E. Rapaport, H.H. Seliger, T.A. Hopkins, Chemi and bioluminescence of firefly luciferin: efficient chemical production of electronically excited states, Bioorg. Chem. 1 (1971) 92-122.

[12] U.K. Laemmli, Cleavage of structural proteins during the assembly of the head of bacteriophage T4, Nature (London) 227 (1970) 680-685.

[13] C.M. Wilson, Staining of proteins on gels: comparison of dyes and procedures, Methods Enzymol. 91 (1983) 236-247.

[14] M.M. Bradford, A rapid sensitive method for quantitation of microgram quantities of rotein utilizing the principle of protein-dye binding, Anal. Biochem. 72 (1976) 248-254.

[15] S. Arrhenius, On the reaction velocity of the inversion of cane sugar by acids, $Z$. Phys. Chem. 4 (1889) 226-228.

[16] A.M. Chase, R. Langridge, The sedimentation constant and molecular weight of Cypridina luciferase, Arch. Biochem. Biophys. 88 (1960) 294-297.

[17] F.I. Tsuji, R. Sowinski, Purification and molecular weight of Cypridina luciferase, J. Cell. Comp. Physiol. 2 (1961) 125-129.

[18] F.I. Tsuji, R.V. Lynch, C.L. Stevens, Properties of luciferase from the bioluminescent crustacean, Cypridina hilgendorfii, Biochemistry 13 (1974) 5204-5209.

[19] T. Rathnayaka, M. Tawa, S. Sohya, M. Yohda, Y. Kuroda, Biophysical characterization of highly active recombinant Gaussia luciferase expressed in Escherichia coli, Biochim. Biophys. Acta 2010 (1804) 1902-1907.
[20] O. Shimomura, Bioluminescence: chemical principles and methods, World Scientific Publishing Co. Pte. Ltd., 2006. pp. 177-348.

[21] S. Inouye, S. Sasaki, Overexpression, purification and characterization of the catalytic component of Oplophorus luciferase in the deep-sea shrimp Oplophorus gracilirostris, Protein Exp. Purif. 56 (2007) 261-268.

[22] R. Bedford, D. LePage, R. Hoffmann, S. Kennedy, T. Gutschenritter, L. Bull, N Sujijantarat, J.C. DiCesare, R.J. Sheaff, Luciferase inhibition by a novel naphthoquinone, J. Photochem. Photobiol., B. 107 (2012) 55-64.

[23] O. Shimomura, T. Masugi, F.H. Johnson, Y. Haneda, Properties and reaction mechanism of the bioluminescence system of the deep-sea shrimp Oplophorus gracilorostris, Biochemistry 17 (1978) 994-998.

[24] F. Dörr, Energetic and statistical relations, in: W. Hoppe, W. Lohman, H. Markl, H. Ziegler (Eds.), Biophysics, Springer-Verlag, Berlin, 1982, pp. 328-330.

[25] T. Rathnayaka, M. Tawa, S. Sohya, M. Yohda, Y. Kuroda, Biophysica characterization of highly active recombinant Gaussia luciferase expressed in Escherichia coli, Biochim. Biophys. Acta 2010 (1804) 1902-1907.

[26] Y. Takenaka, H. Masuda, A. Yamaguchi, S. Nishikawa, Y. Shigeri, Y. Yoshida, H. Mizuno, Two forms of secreted and thermostable luciferases from the marine copepod crustacean, Metridia pacifica, Gene 425 (2008) 28-35.

[27] Y. Nakajima, K. Kobayashi, K. Yamagishi, T. Enomoto, Y. Ohmiya, CDNA cloning and characterization of a secreted luciferase from the luminous Japanese ostracod, Cypridina noctiluca, Biosci. Biotechnol. Biochem. 68 (2004) 565-570.

[28] S. Inouye, Y. Sahara, Identification of two catalytic domains in a luciferase secreted by the copepod Gaussia princeps, Biochem. Biophys. Res. Commun. 365 (2008) 96-101.

29] K. Teranishi, O. Shimomura, Bioluminescence of the arm light organs of the luminous squid Watasenia scintillans, Biochim. Biophys. Acta 1780 (2008) 784792.

[30] G.A. Stepanyuk, H. Xu, C.K. Wu, S.V. Markova, J. Lee, E.S. Vysotski, B.C. Wang, Expression, purification and characterization of the secreted luciferase of the copepod Metridia longa from Sf9 insect cells, Protein. Exp. Purif. 61 (2008) $142-148$.

[31] O. Shimomura, P. R. Flood, S. Inouye, B. Brayan, A Shimomura, Isolation and properties of the luciferase stored in the ovary of the scyphozoan medusa Periphyla periphylla, Biol. Bull. 201 (2001) 339-347.

[32] S. Inouye, Blue fluorescent protein from the calcium-sensitive photoprotein aequorin is a heat resistant enzyme, catalyzing the oxidation of coelenterazine, FEBS Lett. 577 (2004) 105-110.

[33] S. Inouye, S. Sasaki, Imidazole-assisted catalysis of luminescence reaction in blue fluorescent protein from the photoprotein aequorin, Biochem. Biophys. Res. Commun. 354 (2007) 650-655.

[34] O. Shimomura, Luminescence of aequorin is triggered by the binding of two calcium ions, Biochem. Biophys. Res. Commun. 211 (1995) 359-363.

[35] Y. Takenaka, H. Masuda, A. Yamaguchi, S. Nishikawa, Y. Shigeri, Y. Yoshida, H Mizuno, Two forms of secreted and thermostable luciferases from the marine copepod crustacean, Metridia pacifica, Gene 425 (2008) 28-35.

[36] F.I. Tsuji, Bioluminescence reaction catalyzed by membrane-bound luciferase in the "fire fly squid", Watasenia scintillans, Biochim. Biophys. Acta 1564 (2002) 189-197. 